\title{
Forkhead Box Protein Q1
}

National Cancer Institute

\section{Source}

National Cancer Institute. Forkhead Box Protein Q1. NCI Thesaurus. Code C115325.

Forkhead box protein Q1 (403 aa, $42 \mathrm{kDa}$ ) is encoded by the human FOXQ1 gene. This protein is involved in embryonic development. 